\title{
PERSISTENCE OF BROMACIL IN SOILS WITH DIFFERENT MANAGEMENT HISTORIES
}

\author{
P. SANDERS, D. WARDLE and A. RAHMAN \\ AgResearch, Ruakura Agricultural Research Centre, \\ Private Bag 3123, Hamilton
}

\begin{abstract}
Two trials on a soil with no previous bromacil use showed that bromacil was degraded within 4 to 6 months when single applications were used, but persisted in the top $75 \mathrm{~mm}$ of soil for nearly a year when two applications were used in the same season. A third trial on a similar soil with a 10 year history of asparagus management and associated bromacil use showed increased chemical residue levels in lower depths of soil and slower degradation rates. Microbial biomass and activity in the first of these trials indicated that two bromacil applications caused considerable stress on the soil microflora, possibly contributing to the retarded bromacil degradation with repeated bromacil usage.

Keywords: asparagus, Asparagus officinalis, bromacil, herbicide persistence, soil residues
\end{abstract}

\section{INTRODUCTION}

Weed control in asparagus crops in New Zealand relies extensively on the use of soil applied herbicides with long residual activity. Two such products commonly used are bromacil and terbumeton/terbuthylazine which at label use rates can give up to 6 months control of weeds in asparagus. In an earlier field survey of chemical residues in established asparagus crops, sites in which two applications of bromacil at label rates had been applied unexpectedly had lower residues (eleven months later) than sites with a single application (Rahman and Sanders 1990). It was speculated that enhanced biological degradation of bromacil was occurring with two applications.

Bromacil has a half life of 4 to 5 months when applied at $4.4 \mathrm{~kg} / \mathrm{ha}$ to the surface of Butletown silt loam (Gardiner et al. 1969). Losses from photodecomposition and volatilization are negligible (Bingeman et al. 1962). Adsorption on soil colloids is less than with other herbicides. Bromacil is more mobile in the soil than other comparable herbicides (Rhodes et al. 1970) and has been detected at depths of $300 \mathrm{~mm}$ following repeat annual applications (Sanders unpublished). Bromacil is apparently degraded mainly by soil microbes and several taxa of microorganisms are involved in the process (Reid 1963; Torgeson and Mee 1967). The purpose of this study was to investigate the rate of degradation of bromacil in a single soil type but with different previous management histories and to evaluate whether there was a linkage between microbial activity and patterns of herbicide breakdown.

\section{Field trials}

\section{METHODS}

Trial 1 was conducted on a pasture site with no history of bromacil use (virgin soil) at the Rukuhia Horticultural Research Station near Hamilton; the site was cultivated in the winter of 1990. Bromacil (Hyvar X) treatments were applied to this site on 13.9.90 and 18.12.90. Rates and timings were chosen to simulate normal field use in asparagus crops. Two further trials with identical herbicide treatments were conducted the following season on the same soil type. Trial 2 was on a pasture site (virgin soil) and prepared as above while Trial 3 was conducted in an asparagus block with a history of bromacil use (history soil), having received an annual application of approximately 
$1.8 \mathrm{~kg} / \mathrm{ha}$ of bromacil each September for the previous 10 years. Treatments were applied on 10.9.91 and 17.12.91. All treatments were applied in 300 litres/ha of water at $210 \mathrm{kPa}$ using a precision plot sprayer. Each trial consisted of 4 replicates with treatments laid out in a randomised block design with a plot size of $5 \mathrm{~m} \times 2 \mathrm{~m}$. Monthly soil sampling began in December 1990 (Trial 1) or December 1991 (Trials 2 and 3), 3 months after the September application. Samples consisting of $75 \mathrm{~mm}$ diameter cores of soil were taken to a depth of $300 \mathrm{~mm}$ and divided into 4 depths, 0-75, 75-150, 150-225 and 225-300 $\mathrm{mm}$. Three samples were taken from each plot and each depth was bulked within plots. Herbicide residues in the soil were then measured by glasshouse bioassays using oats (Avena sativa L. cv. Amuri) and radish (Raphanus sativus L.) as test species (Rahman et al. 1993). Leaves and stems of the bioassay plants were harvested when maximum damage was assessed to have been reached (i.e. after about 4 weeks) and the relative dry matter production was used to determine the residual activity of bromacil.

\section{Soil microbial activity}

Measurements of the soil microbial respiratory activity and metabolic quotient which is a relative measure of the microbial respiration:biomass ratio, inversely related to microbial efficiency (Anderson and Domsch 1985) were made on the virgin soil of Trial 1. At each sampling date, five soil cores (50 $\mathrm{mm}$ diameter $\times 75 \mathrm{~mm}$ deep) were collected from each plot, bulked and passed through a $4 \mathrm{~mm}$ sieve. Immediately before analysis, the soils were adjusted to $55 \%$ moisture content on a dry weight (DW) basis either by rewetting or gradual air drying. Basal respiration was determined by $\mathrm{CO}_{2}$ evolution for $15 \mathrm{~g}$ soil (DW) between 1 and 4 hours of incubation at $22{ }^{\circ} \mathrm{C}$, as described by Wardle et al. (1993). Substrate-induced respiration (a relative measure of the microbial biomass) was determined as for basal respiration but amended with glucose $(6000 \mathrm{mg} / \mathrm{g}$ soil) immediately prior to incubation. The ratio of the basal to substrate-induced respiration was used as a relative measure of the metabolic quotient (Anderson and Domsch 1985).

\section{Field trials}

\section{RESULTS AND DISCUSSION}

Radish was slightly more sensitive to bromacil than oats but results obtained from the two bioassay species were similar. Table 1 shows the dry matter production of oats as a percentage of untreated control over two critical periods: up to six months after the September application (Dec - March) and for a further 10 months (April - Jan). Average dry matter yields over four depths in Trials 1 and 2 were slightly depressed but residues did not persist beyond March. The repeat application of bromacil (Sept + Dec) caused much greater reduction in initial yields than single applications and persisted for a longer time. The actual dry matter yields of the untreated controls presented at the bottom of Table 1 shows yields in Trial 3 averaged only $76 \%$ of that in Trials 1 and 2 and the likely explanation is the carry over of bromacil used in previous years in the management of the asparagus crop. The three bromacil treatments in Trial 3 reduced average yields to between 38 and $66 \%$ of untreated control as the chemical affected all depths of the soil profile, and maintained residual activity for the duration of the trial.

Results presented in Fig. 1 indicated that bromacil remained at phytotoxic levels in the 0-75 mm soil depth in Trial 2 for up to six months after the September treatment and three to five months after the December treatment. In contrast, phytotoxic levels of bromacil in the repeat treatment persisted for up to 11 months after the date of the first application. Movement of bromacil into the $75-150 \mathrm{~mm}$ profile did not appear to take place with the single applications in Trial 2, but was evident in the case of the repeat application, reducing dry matter yields of oats by approximately half for about 8 months from February to September (Fig. 1) and radish yields by over $70 \%$ for 12 months (data not presented). Bromacil was detected in the $150-300 \mathrm{~mm}$ layers only by the radish bioassays for the repeat treatment from 10 to 14 months after application. Results of Trial 1 showed trends very similar to that presented for Trial 2 in Fig. 1. 
TABLE 1: Dry matter yield of oats as percentage of untreated controls grown in soil collected at monthly intervals after bromacil treatment. Results are the mean of four depths of sampling and two periods of time (3 to 6 months and 7 to 16 months after the September application).

\begin{tabular}{llcccccc}
\hline & & \multicolumn{3}{c}{$\begin{array}{c}\text { DM of oats as a percentage of } \\
\text { Trial 1 } \\
\text { (virgin soil) }\end{array}$} & $\begin{array}{c}\text { Trial 2 } \\
\text { (virgin soil) }\end{array}$ & $\begin{array}{c}\text { Trial 3 } \\
\text { (history soil) }\end{array}$ \\
$\begin{array}{l}\text { Treatment } \\
\text { date }\end{array}$ & $\begin{array}{l}\text { Rate } \\
\text { (kg ai/ha) }\end{array}$ & $\begin{array}{c}\text { Dec- } \\
\text { March }\end{array}$ & $\begin{array}{c}\text { April- } \\
\text { Jan }\end{array}$ & $\begin{array}{c}\text { Dec- } \\
\text { March }\end{array}$ & $\begin{array}{c}\text { April- } \\
\text { Jan }\end{array}$ & $\begin{array}{c}\text { Dec- } \\
\text { March }\end{array}$ & $\begin{array}{c}\text { April- } \\
\text { Jan }\end{array}$ \\
\hline Sept & 1.6 & 72 & 102 & 101 & 92 & 66 & 53 \\
Dec & 1.2 & 85 & 103 & 69 & 96 & 44 & 55 \\
Sept + Dec & $1.6+1.2$ & 59 & 82 & 52 & 76 & 43 & 38 \\
$\begin{array}{l}\text { SED } \\
\text { Mean yield of } \\
\text { untreated/pot (g) }\end{array}$ & 7.9 & 8.3 & 7.6 & 4.8 & 10.4 & 8.6 & \\
\hline
\end{tabular}

1 Trial 1 sampling months from Dec 1990 - Jan 1992; Trials 2 and 3 from Dec 1991 to Jan 1993.

TRIAL 2

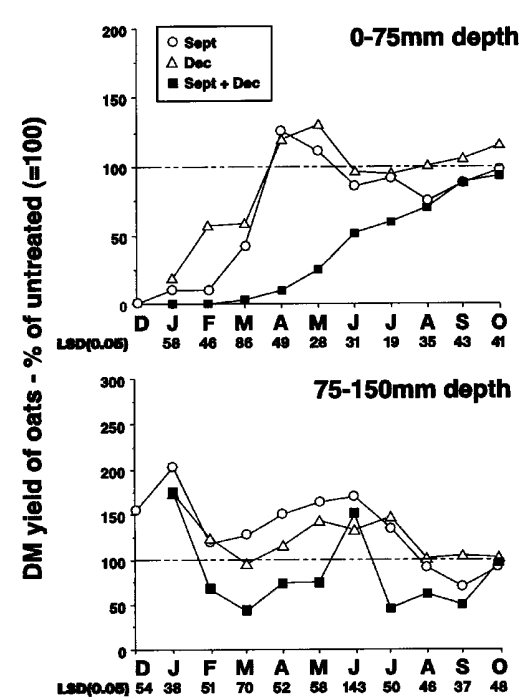

TRIAL 3

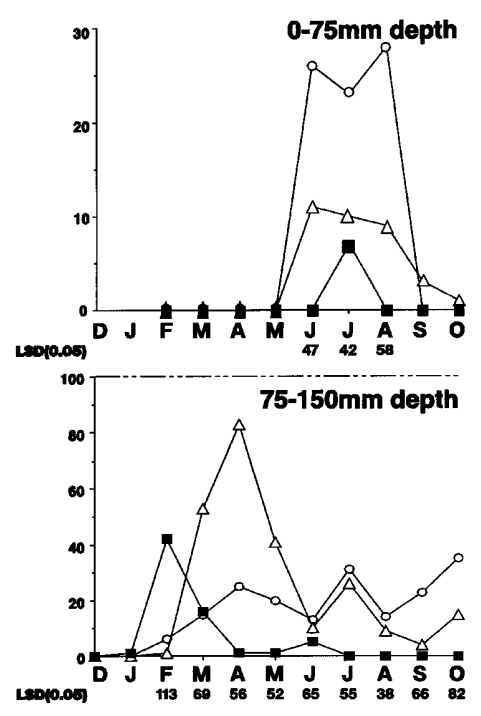

Sampling time (month after bromacil treatment)

FIGURE 1: Dry matter yield of oats as percentage of untreated control, grown in soil collected at monthly intervals ( 3 to 13 months) after bromacil treatment. LSDs $(0.05)$ do not apply to treatment $($ Sept + Dec) if yield is less than $10 \%$. 
In the untreated control soil samples of Trial 3 (history soil), the bioassay species all died in the 0-75 mm depth for the first two samplings (Dec. and Jan.). In addition, all three bromacil treatments showed high levels of phytotoxicity throughout the duration of the trial (Fig. 1). This was probably the result of carryover of bromacil residues from previous years use in the asparagus crop as mentioned earlier. Leaching of the herbicide from all bromacil treatments into the 75-150 mm layer of soil resulted in residues which persisted for more than a year. Residues of a lesser amount were also detected in the 150 - $255 \mathrm{~mm}$ soil layer for the same duration (data not presented). There was little evidence of residues in the 225-300 $\mathrm{mm}$ depth from the single applications although in the repeat treatment, phytotoxicity was recorded at this depth in the August sampling, while the more sensitive radish assays confirmed activity for most of the sampling period.

Results of the three trials on degradation of bromacil presented here are in keeping with normal expectations of the degradation of herbicides, although they are in contrast to the results of our earlier field survey (Rahman and Sanders 1990). The modification of the degradation of bromacil observed in the soil with previous use history (Trial 3) cf. virgin soil (Trials 1 and 2), is probably related to differences in management history of the asparagus crop, which includes prior herbicide history.

\section{Soil microbial activity}

Substrate-induced respiration (and therefore soil microbial biomass) was significantly reduced by addition of bromacil (Fig. 2), and this effect was apparent for much of the 11 month period after the September application. The magnitude of this effect was the same irrespective of when the herbicide was applied, or whether it was applied once or twice. The differences between treated and untreated plots were smaller in December and January compared to the other sampling times, probably because effects of soil moisture deficits were over-riding herbicide side effects. The effects we observed appear greater than the majority of herbicide effects reported in the literature (Wardle 1995), and this appears to be a direct effect since all the plots were kept weed free. However, these effects were probably less than the fluctuations caused by climatic factors. Since the magnitude of the microbial biomass is a key factor in regulating pesticide decomposition rate (Anderson 1984), our results suggest that the toxic effects of bromacil on the microbial biomass could delay its breakdown at least initially. It is conceivable, however, that in the longer term a subset of the microflora would become adapted to these effects.

The basal respiration:substrate induced respiration ratio is enhanced when the microbial biomass is stressed or disturbed and acting inefficiently, and is wasting a
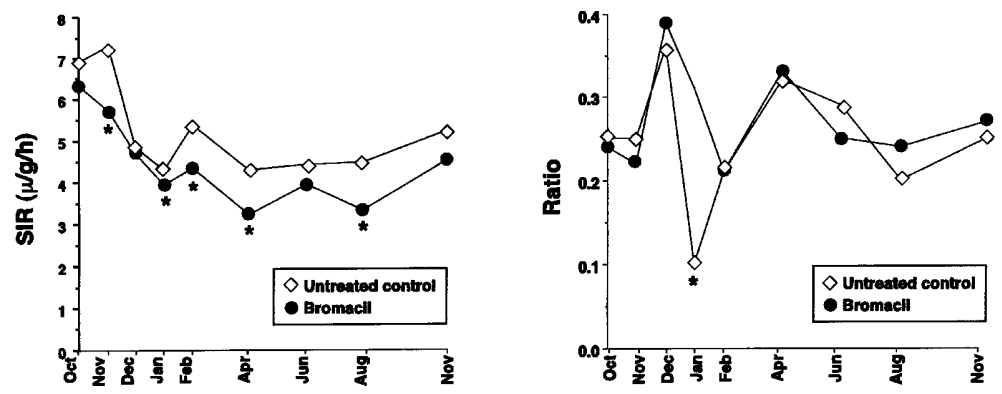

FIGURE 2: Data for substrate induced respiration (SIR mg/g/h) and metabolic quotient (ratio basal to substrate-induced respiration) for the untreated control and mean of three bromacil treatments for sampling times from Trial 1 (virgin soil). 
higher proportion of its carbon resources as respired $\mathrm{CO}_{2}$ (Anderson and Domsch 1985). Our results demonstrate that this ratio was enhanced considerably in January, and the magnitude was independent of how or when the herbicide was applied (Fig. 2). This ratio indicates a transient, but significant stress effect on the soil microflora, which may interfere with the ability of the microbial biomass to degrade bromacil during repeated applications.

\section{CONCLUSION}

Results from this work suggest that sites with different land use history may have different degradation patterns of bromacil, and it is likely that bromacil degradation is slower in soils in which asparagus production has continued for several years. Persistence, movement and degradation of bromacil is of considerable importance to asparagus growers as it relates to weed control, likely risk to the crop and potential carryover effects of repeat usage, particularly towards the end of the crop's life.

\section{REFERENCES}

Anderson, J.P.E., 1984. Herbicide degradation in soil: influence of microbial biomass. Soil Bio. Biochem. 16: 483-489.

Anderson, T.H. and Domsch, K.H., 1985. Determination of ecophysiological maintenance carbon requirements of soil microorganisms in a dominant state. Biol. and Fert. of Soils 1: 81-89.

Bingeman, C.W., Hill, G.D., Varner, R.W. and Weidenfeller, T.A., 1962. Substituted uracils for industrial weed control. Proc. 19th North Central Weed Control Conf: 42-43.

Gardiner, J.A., Rhodes, R.C., Adams, J.B. and Soboczenski, E.J., 1969. Synthesis and studies with 2-C $\mathrm{C}^{14}$-labelled bromacil and terbacil. J. Agric. Food Chem. 17: 980986.

Rahman, A., James, T.K. and Günther, P., 1993. Bioassays of soil applied herbicides. Proc. Int. Symposium on Integrated Weed Management for Sustainable Agriculture. Vol. 1: 95-106.

Rahman, A. and Sanders, P., 1990. Assessment of herbicide residues in fields of established asparagus. Proc. 43rd N.Z. Weed and Pest Control Conf.: 56-59.

Reid, J.T., 1963. Science for the Farmer X(4) Spring: 14.

Rhodes, R.C., Belasco, I.J. and Pease, H.L., 1970. Determination of mobility and adsorption of agrichemicals on soils. J. Agric. Food Chem. 18(3): 524-528.

Torgeson, D.C. and Mee, H., 1967. Microbial degradation of bromacil. Proc. 21st Northeastern Weed Control Conf:: 584.

Wardle D.A., 1995. Impact of disturbance on detritus food webs in agro-ecosystems of contrasting tillage and weed management practises. Advances in Ecol. Res. 26 : 105-185..

Wardle, D.A., Yeates, G.W., Watson, R.N. and Nicholson, K.S., 1993. Response of the soil microbial biomass and plant litter decomposition to weed management strategies in maize and asparagus cropping systems. Soil Biol. Biochem. 25: 857868. 